\title{
INTERPRETACIÓN Y APLICACIÓN DE NORMAS INTERNACIONALES SOBRE DERECHOS HUMANOS EN MATERIAS PENAL Y DISCIPLINARIA*
}

Carlos Arturo Gómez Pavajeau**

\begin{abstract}
Resumen: el Derecho Penal ha dejado de ser, en cuanto sus fuentes de aplicación del derecho, el compendio de normas consignadas en un Código Penal. No puede entenderse hoy el mismo de espaldas a la normatividad constitucional y por allí también necesita ser fundamentado y complementado con los Tratados Internacionales sobre Derechos Humanos. Tan compleja simbiosis está apenas a medio camino de cumplirse; de hecho, se aplica muy deficientemente, toda vez que existen reglas de interpretación consignadas en los instrumentos internacionales que demandan un especial cuidado con su propia aplicación, pues en no pocas ocasiones se cree cumplir con los compromisos internacionales aplicando dichas normas, pero en el fondo el efecto puede ser contrario, si no
\end{abstract}

* Este trabajo de investigación surgió a partir de dos escritos publicados con la Defensoría del Pueblo en 2013 en el trabajo colectivo "Estudios de Derecho Penal y Procesal Penal”. De allí se extraen los conceptos generales que aquí se presentan y se integran algunos resultados con jurisprudencia constitucional anteriormente no considerada.

** Abogado de la Universidad Externado de Colombia, especializado en Ciencias Penales y Criminológicas en la misma universidad. Profesor titular de Derecho Penal y Derecho Disciplinario en esta casa de estudios.Contacto: gomezpavajeau@ hotmail.com. Fecha de recepción: 30 de mayo de 2013. Fecha de modificación: 3 de julio de 2013. Fecha de aceptación: 15 de julio de 2013. Para citar el artículo: CARLOS ARTURO GómEZ PAVAJEAU. "Interpretación y aplicación de normas internacionales sobre Derechos Humanos en materias penal y disciplinaria”, Revista Derecho Penal y Criminología, vol. 34, No. 96, enero-junio 2013, Bogotá, Universidad Externado de Colombia, 2013, pp. 187-218. 
se siguen correctamente las reglas de hermenéutica diseñadas para integrar la legislación de los Estados nacionales con el Orden Público Internacional de los Derechos Humanos.

Palabras clave: Orden Público Internacional de los Derechos Humanos, principios del mejor estándar de garantías internacionales, del mejor estándar de garantías nacionales y de progresividad.

\title{
INTERPRETATION AND APPLICATION OF INTERNATIONAL HUMAN RIGHTS STANDARDS IN CRIMINAL AND DISCIPLINARY MATTERS
}

\begin{abstract}
The Criminal Law, as a law enforcement source, has ceased to be the compendium of rules contained in the Criminal Code. Today it cannot be understood without acknowledging of constitutional norms. Also it needs to be informed and complemented by international human rights treaties. This complex symbiosis is just half way, in fact it is very poorly applied, since there are rules of interpretation set forth in the international instruments that require special care. On many occasions it is believed that they comply with international commitments applying these rules, but sometimes it has the contrary effect when it doesn't followed properly hermeneutical rules designed to integrate national laws of States with the International Public Order of Human Rights.

Keywords: International Public Order of Human Rights, principles of better standard guarantees, the highest standard of national guarantees and progressivity.
\end{abstract}

\section{INTRODUCCIÓN}

En Colombia hasta la entrada en vigencia de la Carta Política de 1991 vivíamos en un absoluto y acuciante solipsismo jurídico. La idea de soberanía absoluta y nacionalidad, proveniente del positivismo decimonónico, nos cautivó y generaciones enteras de juristas se formaron bajo la idea de que las únicas normas jurídicas de vinculante acatamiento por los jueces de la República eran las nacionales, de tal manera que los Tratados Internacionales sobre Derechos Humanos suscritos por nuestro país y convertidos en legislación interna a través de su aprobación por el Congreso de la República eran una forma de honrar los compromisos internacionales de "labios para afuera", muy seguramente para disimular estatus de sociedad civilizada, sin que, a nivel interno, se les presentara la menor atención.

La Carta Política de 1991 globalizó el concepto de juridicidad, puesto que introdujo a nuestro país en el concierto del constitucionalismo moderno con el reconocimiento de los Derechos Fundamentales como elementos irradiantes de todo el ordenamiento 
jurídico interno (artículos 4, 5, 9 y 94), apuntalados con la noción del bloque de constitucionalidad (artículo 93).

Sin embargo, la traslación mecánica y acrítica de las normas internacionales sobre Derechos Humanos ha opacado tan encomiable como significativa tarea, pues se ha vuelto lugar común ver cómo en las decisiones judiciales se acude a la aplicación de las mismas sin cumplir de lleno con los criterios que los mismos tratados internacionales han dispuesto para los efectos de interpretación y aplicación de sus normas en los ámbitos internos de los Estados nacionales, muchas veces por tal vía, con la muy buena intención de superar el solipsismo jurídico de antaño, incumpliendo a la larga y en esencia con el fin y espíritu de los mencionados.

Sin duda alguna tal fenómeno ha tenido su impulso en la llamada constitucionalización del derecho infraconstitucional, muy especialmente en el ámbito del Derecho Penal ${ }^{1}$, toda vez que dicho campo es el que mayor sensibilidad presenta frente al fenómeno de los efectos irradiantes de los Derechos Fundamentales en la ley ${ }^{2}$, pero muy especialmente por cuanto gran parte de la materia de que se ocupan los Tratados Internacionales se encuentra referida a dicho tema.

Alguna doctrina que afortunadamente no ha sido profética en Colombia advertía, con negros nubarrones, que la constitucionalización del Derecho Penal resultaría convirtiéndose en un riesgo para las libertades individuales, dado que si bien una postura del control constitucional a partir del concepto de "prohibición de exceso" resultaba minimalista, no sucedía lo mismo con el manejo del concepto de "prohibición de defecto" que se le atribuiría a la ley penal, lo cual por supuesto generaría un efecto expansivo de aquel.

No obstante, muy a pesar de que no es lugar para tratar el punto, se constata que en términos generales el control de constitucionalidad en Colombia, ejercido por la Corte Constitucional, ha sido fructífero desde la perspectiva de la generación de un

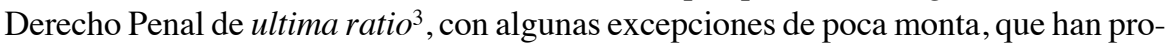
ducido un efecto adverso pero ya no en la extensión de la punición legal por orden de creación de nuevos delitos, sino en la supresión de algún elemento o adición de otro

1 Sobre el concepto de Derecho Penal Constitucional consultar: Gómez Pavajeau, Carlos Arturo. Es tudios de Dogmática en el Nuevo Código Penal, primera y segunda parte, Bogotá, Ediciones Jurídicas Gustavo Ibáñez, 2004, y Gómez Pavajeau, Carlos Arturo. Introducción al Derecho Penal Constitucional, Bogotá, Ediciones Nueva Jurídica, 2012.

2 Paradigmática la sentencia de febrero 27 de 2013, radicación n. ${ }^{\circ} 33.254$, con ponencia del magistrado Bustos Martínez proferida por la Sala de Casación Penal de la Corte Suprema de Justicia.

3 Por citar un ejemplo contundente, basta echar una desprevenida observación a lo que ha significado meter en "cintura constitucional" el tan denostado derecho penal paralelo que se generaba a borbotones con el ejercicio de facultades legisferantes extraordinarias en materia penal, surgidas a partir de la declaratoria del llamado "Estado de sitio", hoy "Estado de conmoción interior" (artículo 213 de la Carta Política). 
que llevan al aumento de la drasticidad de la pena ${ }^{4}$. El balance, hay que reconocerlo, ha resultado positivo y por tal vía, al crear precedentes judiciales vinculantes, nuestro Derecho Penal se mantiene en gran medida en niveles aceptables dictados por el liberalismo penal.

Empero, hay que reconocerlo, no todo es felicidad en la medida en que a partir del bloque de constitucionalidad se ha convertido en lugar común citar una que otra norma internacional para apoyar normativamente las decisiones judiciales, sin pasar por un tamiz previo de análisis crítico dicha traslación, generando una aplicación automática, sin más ni más, de las mismas al ordenamiento jurídico interno. Tal forma de proceder, si no se afinan los instrumentos de interpretación y aplicación de las normas internacionales al concierto nacional, puede terminar por violentar de manera grosera los tratados internacionales mismos que se dice respetar.

A través del presente escrito quiero demostrar:

1) Cualquier norma internacional sobre Derechos Humanos que se invoque en Colombia debe pasar por un examen del bloque de constitucionalidad a partir del cual se dictamine:

a) Que la norma a aplicar represente el mejor estándar de garantías que ofrece el Orden Público Internacional de los Derechos Humanos;

b) Que el estándar de garantías determinado internacionalmente supere al estándar de garantías que emana de la Carta Política; y

c) Que no se desconozca con ello el principio de progresividad en materia de mejoría de los estándares de garantías.

2) Si tal test riguroso se ofrece como una talanquera que permite escoger el mejor estándar de garantías cuando de aplicar Tratados Internacionales sobre Derechos Humanos se trata, con mayor razón así debe procederse cuando se interpreta nuestro Derecho Penal a la luz de las doctrinas que nos aporta el Derecho Comparado, por muy importante y significativo que resulte, en su país o en el concierto internacional, el autor del cual pretendamos nutrirnos en materia dogmática.

Los presupuestos para llevar a cabo tal ejercicio son:

4 Sentencias C-087 de 1997, C-177 de 2001, C-330 de 2001, C-551 de 2001, C-675 de 2001, C-317 de 2002, C-622 de 2003, C-034 de 2005, C-148 de 2005, C-674 de 2005, C-335 de 2006, C-822 de 2006, C-291 de 2007, C-798 de 2008, C-029 de 2009, C-468 de 2009, C-488 de 2009 y C-100 de 2011. 


\section{EL CONCEPTO DE ORDEN PÚBLICO INTERNACIONAL DE LOS DERECHOS HUMANOS}

La interpretación a partir de la Dogmática como Ciencia del Derecho se constituye en el mejor instrumento para racionalizar e introducir razonabilidad en la hermenéutica de las normas jurídicas, en tanto se entiende como un supramétodo de interpretación integral e integrado, cuyo producto que es la Teoría Jurídica se constituye en un plus respecto de la ley; se evita así en gran medida la subjetividad y la arbitrariedad del intérprete en la aplicación de la norma, al enmarcar a aquella en el ámbito de los valores objetivos del sistema constitucional, coadyuvada por el carácter ecuménico que le aporta el Orden Público Internacional de los Derechos Humanos ${ }^{5}$.

El artículo 93 de la Carta Política sugiere la necesidad de acudir a una categoría jurídica como es la de Orden Público Internacional de los Derechos Humanos, puesto que menciona en plural y por supuesto da cuenta de una pléyade de tratados internacionales suscritos e incorporados a la legislación interna, como concierto de normas internacionales que se encuentran llamadas a conformar el bloque de constitucionalidad.

Tal idea ya venía prefigurada desde la expedición de la Declaración Universal de los Derechos Humanos (en adelante DUDH), toda vez que, en su artículo 28, establecía:

Toda persona tiene derecho a que se establezca un orden social e internacional en el que los derechos y libertades proclamados en esta Declaración se hagan plenamente efectivos.

La DUDH no ha sido adoptada como instrumento jurídico por Colombia en forma expresa; no obstante, su efecto vinculante de tal naturaleza viene impuesto por ser considerada "derecho consuetudinario" con fuerza de ius cogens ${ }^{6}$.

5 Una aproximación a ello en Gómez Pavajeau, Carlos Arturo. La dogmática como Ciencia del Derecho. Sus especies penal y disciplinaria. Necesidades, semejanzas y diferencias, Bogotá, Universidad Externado de Colombia, 2011.

6 Buergenthal, TomÁs. International Human Rigths in a Nutshell, $2^{\mathrm{a}}$ ed., West Group, 1990. Así también el literal b) del artículo 38 del Estatuto de la Corte Internacional de Justicia, que enseña el derecho aplicable o fuentes del derecho internacional de los derechos humanos: "la costumbre internacional como prueba de una práctica generalmente aceptada como derecho". Otro autor afirma que "jurídicamente, su significación no es otra (al igual de las declaraciones de derechos en los ordenamientos internos) que la de una pauta superior de interpretación para los órganos llamados a configurar, desarrollándolo convencional o consuetudinariamente y en todo caso aplicándolo por vía judicial o arbitral, el derecho internacional positivo... La Declaración es indudablemente la expresión de la conciencia jurídica de la humanidad, representada en la ONU y, como tal, fuente de un derecho superior, un higher law, cuyos principios no pueden desconocer sus miembros. Pero es admisible incluso afirmar que la Declaración no carece de valor jurídico-positivo estrictamente hablando. Porque en cierto modo viene a constituir un desarrollo o una interpretación, y como tal cabe considerarla"; TRUYOL y SERRA, ANTONIO. Los derechos humanos, Madrid, Tecnos, 1994, pp. 31 y 32. También, en nuestro ámbito jurídico, por la mención "implícita" que de ella hace el párrafo tercero de su preámbulo y el literal d) del artículo 29 de la Convención Americana sobre Derechos Humanos que dispone que ninguna disposición de la presente 
El Pacto Internacional de Derechos Civiles y Políticos (en adelante PIDCP), como instrumento perteneciente al concierto de las Naciones Unidas, reconoce en su parte considerativa que su fuente de origen es la Declaración Universal de los Derechos Humanos, tal como también lo hace en la misma parte el Pacto Internacional de Derechos Económicos, Sociales y Culturales (en adelante PIDESC) ${ }^{7}$.

La Declaración Americana de los Derechos y Deberes del Hombre ${ }^{8}$ (en adelante DADDH) establece en su considerando n. ${ }^{\circ}$ :

Que la consagración americana de los derechos esenciales del hombre unida a las garantías ofrecidas por el régimen interno de los Estados, establece el sistema inicial de protección que los Estados americanos consideran adecuado a las actuales circunstancias sociales y jurídicas, no sin reconocer que deberán fortalecerlo cada vez más en el campo internacional, a medida que esas circunstancias vayan siendo más propicias. (Resaltado fuera de texto).

Se deduce, a partir de lo resaltado, que se da cuenta de un sistema de protección y que ese sistema es apenas inicial, no acabado, tendiendo siempre a evolucionar, de lo cual surgen las ideas de contexto y dinámica del Orden Público Internacional de los Derechos Humanos.

La Convención Americana sobre Derechos Humanos (en adelante CADH), Pacto de San José de Costa Rica, incorporada a nuestro orden jurídico por la Ley 16 de 1972 fija en la DUDH su fuente de inspiración, la cual es reiterada en sus presupuestos básicos, amén de que además da cuenta que los principios en que se inspira "han sido consagrados en la Carta de la Organización de los Estados Americanos, en la Declaración Americana de los Derechos y Deberes del Hombre y en la Declaración Universal de los Derechos Humanos que han sido reafirmados y desarrollados en otros instrumentos internacionales, tanto del ámbito universal como regional".

Tal entramado de instrumentos internacionales, informados por unos principios básicos comunes, conforma el Orden Internacional Público de los Derechos Humanos, además de otras fuentes que se dejan enunciadas en términos generales.

Convención puede ser interpretada en el sentido de "excluir o limitar el efecto que puedan producir la Declaración Americana de los Derechos y Deberes del Hombre y otros actos internacionales de la misma naturaleza" (resaltado fuera de texto).

7 Incorporados a la legislación interna colombiana por medio de la Ley 74 de 1968.

8 Su carácter vinculante deviene del reconocimiento que de la misma hizo, como normatividad que define los Derechos Humanos, el artículo 2 del Estatuto de la Comisión Interamericana de Derechos Humanos adoptado por el Consejo de la OEA en 1960. También de la mención que de ella hace el párrafo tercero de su preámbulo y el literal d) del artículo 29 de la Convención Americana sobre Derechos Humanos que prescribe que ninguna disposición de la presente Convención puede ser interpretada en el sentido de "excluir o limitar el efecto que puedan producir la Declaración Americana de los Derechos y Deberes del Hombre y otros actos internacionales de la misma naturaleza". 
Como se puede ver, el número de instrumentos es pluralmente complejo, pero además es factible y probable que existan estándares diferenciales de garantías entre uno y otro desde el punto de vista cuantitativo y cualitativo, de tal manera que resulta imprescindible que, ante el reconocimiento que de los mismos ha hecho Colombia, se determine cuáles son las reglas de interpretación y aplicación que nos permitan individualizar el mejor estándar de garantías para cumplir con el mandato de la primera parte del inciso 1. ${ }^{\circ}$ del artículo 93 de la Carta Política, según el cual los tratados internacionales "prevalecen en el orden interno".

Ello es necesario, puesto que, ante la viabilidad de tratamientos diferenciales, es obvio, según enseñan los tratados internacionales y veremos a partir de los principios, hay que escoger el mejor estándar de garantías en tanto la segunda parte del inciso antes mencionado establece que "los derechos y deberes consagrados en esta Carta, se interpretarán de conformidad con los tratados internacionales sobre derechos humanos ratificados por Colombia".

Así entonces, no puede desconocerse que ese entramado de normas internacionales forman un sistema, el cual solo puede ser captado a partir de una visión contextual, en la medida en que existen unos hilos conductores y vasos comunicantes que lo cruzan desde arriba hacia abajo y de lado a lado, dentro del cual se hace imperioso el encuentro del mejor estándar de garantía que resulte de su interpretación.

La conexión en ese entramado entre la DUDH y los PIDCP y PIDESC viene dada por lo expuesto en sus partes considerativas, tal como ya se señaló. Pero también, ya en su texto normativo, por sus artículos 46 y 24 , respectivamente.

La conexión entre la DUDH, DADDH y CADH, así como la existente con otros tratados multilaterales y bilaterales sobre la materia, también fue puesta de presente; empero, debe resaltarse cómo ya en el estricto campo normativo el artículo 29-sobre "Normas de interpretación"- del Pacto de San José de Costa Rica, en su literal b), da razón de la necesidad de tener en cuenta en el juicio de búsqueda del mejor estándar de garantías a nivel internacional cualquier "otra convención en que sea parte uno de dichos Estados", es decir, cualquier otro tratado multilateral o bilateral suscrito.

Por ello, el mismo artículo 29 en su literal d) enseña que ninguna disposición de la CADH puede ser interpretada en el sentido de "excluir o limitar el efecto que puedan producir la Declaración Americana de Derechos y Deberes del Hombre y otros actos internacionales de la misma naturaleza".

Por lo general, la discusión aquí tratada viene referida a la materia penal; no obstante, es claro que también se aplica a otros espacios del llamado derecho sancionador administrativo y, particularmente, al Derecho Disciplinario.

En el ámbito de las Naciones Unidas pareciera que las "garantías judiciales" solo están referidas a la materia penal y dentro de ella estrictamente a lo judicial, según las 
expresiones utilizadas al efecto por los artículos 14 y 15 del PIDCP; no obstante, otra cosa surge si se interpretan de manera contextual y sistemática sus normas, pues, si se mira bien y sin prevención de ninguna clase, se encontrarán allí otras que indican que también las reglas sobre prohibición de injerencias ilegales o arbitrarias en la vida de las personas se aplican en materias diferentes a la penal y en procedimientos que tengan naturaleza administrativa, habida cuenta que el artículo 17 del mismo expresa, de manera categórica y sin distinción alguna, que "nadie será objeto de injerencias arbitrarias o ilegales en su vida privada, su familia, su domicilio o su correspondencia, ni de ataques ilegales a su honra y reputación" y "toda persona tiene derecho a la protección de la ley contra esas injerencias o esos ataques".

Es más, si de los artículos 5 numeral $1 .^{\circ}$ del PIDCP y 5 numeral $1 .^{\circ}$ del PIDESC se desprende que los efectos vinculantes de los Derechos Humanos no solo lo son en sentido vertical -frente al Estado-, sino también horizontal -frente a "grupo o individuo"-, de los primeros no pueden quedar excluidas las autoridades estatales de naturaleza administrativa y el derecho sancionador administrativo en general.

El Tribunal Europeo de derechos Humanos ha extendido las garantías judiciales penales a los procesos administrativos sancionadores, puesto que ha llegado a la conclusión que, cuando los instrumentos internacionales hacen mención de un "tribunal”, se están refiriendo al sentido material del término, esto es, a un órgano que dispensa y resuelve "conforme a reglas de Derecho"9.

La CADH es explícita en su reconocimiento, al señalar que las "garantías judiciales" son también de aplicación en el "orden civil, laboral, fiscal o de cualquier otro carácter" (resaltado fuera de texto).

La Corte Interamericana de Derechos Humanos, de manera sólida, coherente y consistente, así lo ha venido afirmando:

La Corte considera que en todo procedimiento o proceso existente en el orden interno de los Estados deben concurrir amplias garantías judiciales, entre las cuales se encuentran también las formalidades que deben observarse para garantizar el acceso a las mismas. Por razones de seguridad jurídica, para la correcta y funcional administración de justicia y la efectiva protección de los derechos de las personas, los Estados pueden y deben establecer presupuestos y criterios de admisibilidad de los recursos internos, de carácter judicial o de cualquier otra índole. De tal manera, si bien esos recursos internos deben estar disponibles para el interesado y resolver efectiva y fundadamente el asunto planteado, así

9 Tribunal Europeo de Derechos Humanos: i) Caso Albert y Le Compte contra Bélgica. Sentencia de 10 febrero 1983, párrafo n. ${ }^{\circ} 39$; ii) Caso Campbell y Fell contra Reino Unido. Sentencia de 28 junio 1984; iii) Caso H. contra Bélgica. Sentencia de 30 noviembre 1987, párrafo n. ${ }^{\circ}$ 50; y iv) Caso Belilos contra Suiza. Sentencia de 29 abril 1988, párrafo n. 64 . 
como eventualmente proveer la reparación adecuada, no cabría considerar que siempre y en cualquier caso los órganos y tribunales internos deban resolver el fondo del asunto que les es planteado, sin que importe la verificación de los presupuestos formales de admisibilidad y procedencia del particular recurso intentado ${ }^{10}$. (Resaltado fuera de texto).

En efecto, ha reiterado:

Al respecto, la Corte ha indicado que todos los órganos que ejerzan funciones de naturaleza materialmente jurisdiccional, sean penales o no, tienen el deber de adoptar decisiones justas basadas en el respeto pleno a las garantías del debido proceso establecidas en el artículo 8 de la Convención Americana ${ }^{11}$. Asimismo, la Corte recuerda lo expuesto en su jurisprudencia previa en el sentido que las sanciones administrativas y disciplinarias son, como las penales, una expresión del poder punitivo del Estado y que tienen, en ocasiones, naturaleza similar a la de estas ${ }^{12},{ }^{13}$. (Resaltado fuera de texto).

\section{LOS PRINCIPIOS QUE GOBIERNAN LA INTERPRETACIÓN Y APLICACIÓN DE LAS NORMAS INTERNACIONALES SOBRE DERECHOS HUMANOS}

El artículo original de la Carta Política de 1991 se contraía al inciso $1^{\circ}$ de la actual redacción, sin que se previera, a nivel interno, el juicio de vocación del mejor estándar de garantía en la interpretación y aplicación del Orden Público Internacional de los Derechos Humanos. Empero, ello cambió a partir del Acto legislativo n. ${ }^{\circ} 2$ de 2001 , habida cuenta que, al incorporar el Tratado de Roma sobre la Corte Penal Internacional, estableció que "la admisión de un tratamiento diferente en materias sustanciales" por parte de su Estatuto "con respecto a las garantías contenidas en la Constitución tendrá efectos exclusivamente dentro del ámbito de la materia regulada en él”.

La Corte Constitucional, por medio de sentencia C-578 de 2002, al realizar el control previo de constitucionalidad del acto legislativo arriba señalado, se ocupó de definir

10 Corte Interamericana de Derechos Humanos, sentencia de noviembre 24 de 2006. Caso Trabajadores Cesados del Congreso (Aguado Alfaro y otros) vs. Perú, párrafo n. 126.

11 Cfr. Caso Ivcher Bronstein vs. Perú. Fondo, reparaciones y costas. Sentencia de 6 de febrero de 2001. Serie C n. ${ }^{\circ} 74$, párr. 104, y Caso del Tribunal Constitucional vs. Perú. Fondo, reparaciones y costas. Sentencia de 31 de enero de 2001. Serie C n. ${ }^{\circ} 71$, párr. 71.

12 Cfr. Caso Baena Ricardo y otros vs. Panamá. Fondo, reparaciones y costas. Sentencia de 2 de febrero de 2001. Serie C, n. ${ }^{\circ}$ 72, párr. 106, y Caso Vélez Loor vs. Panamá. Excepciones preliminares, fondo, reparaciones y costas. Sentencia de 23 de noviembre de 2010, serie C, n. ${ }^{\circ} 218$, párr. 170 .

13 Corte Interamericana de Derechos Humanos, sentencia de septiembre 1 de 2011, Caso López Mendoza vs. Venezuela, párrafo 111. 
asuntos atinentes a la discusión aquí planteada, tratando los aspectos relacionados con "disposiciones ajenas a la tradición jurídica nacional y ciertos principios constitucionales" y con la "admisión de tratamiento diferente en materias sustanciales respecto a garantías de la Constitución", señalando que un "tratamiento especial solo surtirá efecto dentro del ámbito propio" del Estatuto de Roma a nivel externo, pero no a nivel interno.

Posteriormente, por sentencia C-801 de 2009 referida a las "reglas de procedimiento y prueba y los elementos de los crímenes de la Corte Penal Internacional", reiteró los anteriores criterios manifestando:

Mediante sentencia C-578 de 2002, esta Corporación llevó a cabo el control de constitucionalidad del Estatuto de Roma de la Corte Penal Internacional y de su ley aprobatoria, la Ley 742 de 2002, y en dicho fallo precisó, que el control de constitucionalidad que ejerce sobre los instrumentos internacionales relacionados con el Estatuto de Roma de la Corte Penal Internacional, el tratado propiamente dicho y los acuerdos complementarios que se integran a él, presentan algunas variaciones frente al que tradicionalmente se lleva a cabo sobre los demás tratados y sus respectivas leyes aprobatorias, variación que se evidencia en tratándose del control material, cuya justificación tiene como referente el Acto Legislativo 02 de 2001, reforma constitucional a través de la cual se autorizó al Estado a reconocer la jurisdicción de la Corte Penal Internacional, habida cuenta que ciertas medidas incorporadas al Estatuto podían resultar ajenas a la tradición jurídica nacional y a ciertos valores superiores, resultando del mandato del constituyente derivado, la admisión de un tratamiento diferente en materias sustanciales por parte del Estatuto de Roma, y en su función de control, respecto del citado estatuto, la Corte debe limitarse a constatar si existe alguna diferencia entre este y la Constitución Política, y en caso de que exista, y se trate de una materia sustancial dentro del ámbito de lo regulado por el Estatuto, no se procede a declarar su inexequibilidad, teniendo en cuenta que el propósito de la reforma constitucional fue, precisamente, la de permitir un tratamiento diferente siempre y cuando esta opere exclusivamente dentro del ámbito de aplicación del Estatuto de Roma. De ahí que de encontrar tratamientos diferentes entre los instrumentos internacionales contentivos del Estatuto de Roma y la Constitución, lo que le corresponde hacer a la Corte, es delimitar sus contornos y precisar su ámbito de aplicación, y, además, declarar que ellos han sido autorizados especialmente por el constituyente derivado en el acto legislativo 02 de 2001. Ello sobre la base de que los tratamientos diferentes solo están llamados a producir efectos dentro del propio ámbito de la Corte Penal internacional y no se proyectan sobre el derecho interno del Estado.

Esto es,

... las disposiciones del Estatuto de Roma y los instrumentos que hacen parte del mismo, no remplazan ni modifican las leyes nacionales de tal manera que 
a quien delinca en el territorio nacional se le aplicará el ordenamiento jurídico interno y las autoridades judiciales competentes al efecto son las que integran la administración de justicia colombiana.

Por tanto,

Tratamientos sustanciales diferentes operan exclusivamente dentro del ámbito de aplicación del Estatuto de Roma de la Corte Penal Internacional.

Así, de manera integral, dichos conceptos fueron ratificados por sentencia C-290 de 2012.

Significa lo anterior, sin más ni más, que los tratamientos diferenciales que impliquen una rebaja de los estándares de garantías no tienen aplicación en el orden interno, lo que muestra cómo el Estatuto de Roma también está sometido en su interpretación y aplicación a los principios de hermenéutica que a continuación se tratarán, lo que se evidencia cuando, como se establece en su artículo 21 sobre "Derecho Aplicable", dispone en su numeral 3. ${ }^{\circ}$ :

La aplicación e interpretación del derecho de conformidad con el presente artículo deberá ser compatible con los derechos humanos internacionalmente reconocidos... (Resaltado fuera de texto).

\subsection{El principio del mejor estándar de garantías del contexto internacional}

Visto que existe un sistema integral e integrado de instrumentos internacionales que reconocen la vigencia de una pléyade de Derechos Humanos, es preciso indicar que los mismos no pueden entenderse en forma aislada, forman como tales un contexto y por supuesto cada uno de ellos y cada parte de uno tiene que ser interpretada a partir del todo, por lo que se requiere aplicar un método dogmático para desentrañar su correcto entendimiento.

Solo así, reiteramos, podemos hablar de un Orden Público Internacional de los Derechos Humanos que nos sirva como categoría dogmática imprescindible para solucionar las dudas y problemas a que nos puedan someter cuando se discuta la aplicación de los mismos frente al contraste con los ordenamientos jurídicos de los Estados nacionales. En efecto, el numeral 2..$^{\circ}$ del artículo 5 del PDCP señala que "no podrá admitirse restricción o menoscabo de ninguno de los derechos humanos fundamentales reconocidos o vigentes en un Estado parte en virtud de ... convenciones ..., so pretexto de que en el presente Pacto no los reconoce o los reconoce en menor grado".

Con similar redacción, el numeral 2. ${ }^{\circ}$ del artículo 5 del PDESC establece que "no podrá admitirse restricción o menoscabo de ninguno de los derechos humanos fundamentales 
reconocidos o vigentes en un país en virtud de... convenciones..., a pretexto de que el presente Pacto no los reconoce o los reconoce en menor grado".

Por su parte, la CADH en su artículo 29, dedicado a las “Normas de interpretación”, de manera especialmente enfática dispone que "ninguna disposición de la presente Convención puede ser interpretada en el sentido" de "limitar el goce y el ejercicio de cualquier derecho o libertad que pueda estar reconocido ... de acuerdo con otra convención en que sea parte uno de dichos Estados". De manera expresa, afirma en su literal d) que tampoco puede surgir interpretación alguna que conlleve "excluir o limitar el efecto que puedan producir la Declaración Americana de Derechos y Deberes del Hombre y otros actos internacionales de la misma naturaleza".

Como se puede ver, de las disposiciones citadas:

1) Se confirma la existencia de un Orden Público Internacional de los Derechos Humanos como sistema normativo básico y esencial;

2) La necesidad de interpretar toda norma de dicho sistema normativo a partir del mejor estándar de garantías que se ofrezca; y,

3) Si el mejor estándar de garantía ofrecido se impone sobre otros de menor valía de la misma naturaleza, con mayor razón así tiene que suceder sobre aquellas disposiciones de tratados internacionales suscritos que no se encuentren dentro de la órbita de los Derechos Humanos.

La tercera conclusión es de suma importancia para la actualidad, toda vez que algunos tratados internacionales recientes, tal como sucede con la Convención de las Naciones Unidas contra la Corrupción, aprobada por medio de la Ley 970 de 2005, en algunos aspectos parecieran desconocer el sumun de garantías de que dan cuenta los tratados internacionales sobre Derechos Humanos ${ }^{14}$.

Por ello se requiere, de todas maneras, refinar los criterios de interpretación de las normas contenidas en tratados internacionales, pues estas tienen también, dentro del concierto de jerarquías normativas, ciertos ámbitos de prevalencia y prelación.

Las normas citadas en este aparte son ejemplo paradigmático de ello, pero también lo es la norma de normas, puesto que el artículo 93 de la Carta Política, cuando habla de la prevalencia de los tratados internacionales y su incidencia en la interpretación de

14 No es el escenario para discutir el punto; empero, de alguna manera nos hemos aproximado al tema en Gómez Pavajeau, Carlos Arturo. "La huida del bien jurídico en el ámbito de las leyes de seguridad ciudadana y anticorrupción”, en Aspectos liberales y sociales del Derecho Penal, Bogotá, Ediciones Nueva Jurídica, 2012, pp. 210 y ss. 
los derechos y deberes fundamentales, hace mención expresa, explícita e inequívoca de los "tratados internacionales sobre derechos humanos ratificados por Colombia".

Podría argüirse que, como todo tratado internacional, para ser observado se incorpora a través de ley de la República, la cual, por demás, debe pasar un control previo de constitucionalidad $^{15}$, de tal manera que ya sus disposiciones han sufrido un control de constitucionalidad de conformidad con el numeral 10 del artículo 241 de la Carta Política, sus normas deben ser aplicadas sin más ni más por los jueces de la República; no obstante, se desconocería el sentido de las normas internacionales tratadas y otras que se van a abordar a continuación, que parten de la validez formal de normas internas de los Estados nacionales, pero que de todos modos deben subordinarse al mejor estándar de garantías, como también se desconocería el valor fundante, prevalente y prioritario que tienen los Derechos Humanos en el orden constitucional colombiano (artículos 4, 93 y 214 numeral 2. ${ }^{\circ}$ de la Carta Política).

\subsection{El principio del mejor estándar de garantías ofrecido a partir de una análisis diferencial entre el Orden Público Internacional de los Derechos Humanos y el orden constitucional y legal del Estado nacional ${ }^{16}$}

Establecido el mejor estándar de garantías a nivel internacional, el mismo debe ser confrontado con el de los Estados nacionales, y solo si se aplica el tratado internacional cuando mejore el estándar nacional. Esto es, si el estándar nacional ofrece un mayor

15 Por ejemplo, la ley que aprobó la Convención de las Naciones Unidas contra la Corrupción fue declarada ajustada a la Carta Política por sentencia C-172 de 2006 de la Corte Constitucional.

16 Este principio fue flagrantemente desconocido por la Corte Constitucional en sentencia C-024 de 1994, al desmejorar los estándares de garantías internos acogiendo los menos garantistas del Pacto Internacional de Derechos Civiles y Políticos y de la Convención Americana de Derechos Humanos en el tema de las llamadas "detenciones administrativas", inexistentes en nuestro ordenamiento constitucional:

"Las excepciones constitucionales al anterior régimen de reserva judicial: la flagrancia y la detención preventiva derivada de aprehensión material.

La propia constitución establece sin embargo dos excepciones al anterior régimen constitucional de estricta reserva judicial de la libertad personal y la inviolabilidad del domicilio.

De un lado, el inciso segundo del artículo 28 transcrito en el numeral anterior establece una excepción administrativa para detener preventivamente a una persona hasta por 36 horas. Este inciso establece que al principio de la estricta reserva judicial de la libertad, puesto que consagra la atribución constitucional la 'persona detenida preventivamente será puesta a disposición del juez competente dentro de las treinta y seis horas siguientes para que este adopte la decisión correspondiente en el término que establezca la ley'. Esta norma consagra entonces una facultad para que, en determinadas circunstancias y con ciertas formalidades, autoridades no judiciales aprehendan materialmente a una persona sin contar con previa orden judicial. No de otra manera se entiende la obligación constitucional de que la persona detenida preventivamente sea puesta a disposición del juez, puesto que ello significa que la autoridad judicial no ordena la detención con anterioridad sino que verifica la legalidad de la aprehensión con posterioridad a la ocurrencia de la misma. Es entonces un caso en donde la propia Constitución establece una excepción al principio general de la estricta reserva judicial y consagra la posibilidad de una aprehensión sin previa orden de autoridad judicial. Y no se puede considerar que esta norma se refiere únicamente al 
nivel de garantías, se dejan de lado las normas internacionales, porque así lo ha establecido el Orden Público Internacional de los Derechos Humanos.

De lo anterior se desprende:

\subsubsection{De la obligatoriedad de incorporar a la legislación interna de los Estados nacionales las normas estándares contempladas en el Orden Público Internacional de los Derechos Humanos}

En efecto, el artículo 2 del PIDCP dispone, en su numeral 1. ${ }^{\circ}$, que todo Estado parte "se compromete a respetar y garantizar a todos los individuos que se encuentren en su territorio y estén sujetos a su jurisdicción los derechos reconocidos" en él. Es decir, si no se han reconocido, lo que significa que no existe un estándar nacional de garantías, el deber es de nivelar las garantías nacionales de conformidad con los estándares internacionales.

Por ello, el numeral 2. ${ }^{\circ}$ del mismo artículo preceptúa de manera perentoria que "cada Estado parte se compromete a adoptar, con arreglo a sus procedimientos constitucionales y a las disposiciones del presente Pacto, las medidas oportunas para dictar las disposiciones legislativas o de otro carácter que fueren necesarias para hacer efectivos los derechos reconocidos en el presente Pacto y que no estuvieren ya garantizados por disposiciones legislativas o de otro carácter", cuya efectividad y realización material viene exigida por el artículo 3, según el cual "los Estados Partes en el presente Pacto se comprometen a garantizar a hombres y mujeres la igualdad en el goce de todos los derechos civiles y políticos enunciados en el Presente Pacto".

De igual forma que los anteriores, los artículos 2 , numerales $1 .^{\circ}$ y $2 .^{\circ}$, y 3 del PIDESC, consagran las mismas cláusulas vinculantes.

En el ámbito americano la CADH en su artículo 1, numeral 1. ${ }^{\circ}$, preceptúa que "los Estados Partes en esta Convención se comprometen a respetar los derechos y libertades reconocidos en ella y a garantizar su pleno y libre ejercicio a toda persona que esté sujeta a su jurisdicción", sin discriminación alguna.

\footnotetext{
caso de la flagrancia, puesto que tal evento es regulado por otra disposición constitucional. Consagró entonces el constituyente una más amplia facultad de detención administrativa, lo cual no contradice sino que armoniza plenamente con los tratados internacionales de derechos humanos suscritos por Colombia, de conformidad con los cuales se interpretan los derechos y deberes consagrados por la Constitución (CP, art 93). En efecto, los tratados consagran una protección judicial de la libertad, en virtud de la cual la legitimidad de toda privación de la libertad debe ser controlada por una autoridad judicial independiente. Pero el control puede ser posterior a la aprehensión, puesto que las normas internacionales no establecen que toda privación de la libertad deba ser efecto de una orden judicial, sino que consagran que la persona detenida a causa de una infracción penal deberá ser llevada sin demora ante un juez, y que podrá recurrir ante un tribunal a fin de que este decida a la brevedad posible sobre la legalidad de su prisión y ordene su libertad si la prisión fuera ilegal (Pacto de Derechos Civiles y Políticos, artículos 9-3 y 9-4; Convención Interamericana, artículos 7-5 y 7-6)”.
} 
Pero además, en su artículo 2, dispone que, bajo el nomen iuris de "Deber de Adoptar Disposiciones de Derecho Interno", "si el ejercicio de los derechos y libertades mencionados en el artículo 1 no estuviera ya garantizado por disposiciones legislativas o de otro carácter, los Estados Partes se comprometen a adoptar, con arreglo a sus procedimientos constitucionales y a las disposiciones de esta Convención, las medidas legislativas o de otro carácter que fueren necesarias para hacer efectivos tales derechos y libertades".

\subsubsection{De la cláusula propiamente dicha de la determinación del mejor estándar de garantías que se ofrezca al ponerse en contraste las normas internacionales con las nacionales}

Dos subcláusulas ponen de presente dicho principio de interpretación en el ámbito de los instrumentos sobre Derechos Humanos de las Naciones Unidas:

1) Subcláusula implícita:

Según la cual, por virtud de una interpretación a contrario sensu, se llega a la conclusión de la imperiosa necesidad de escoger el mejor estándar de garantías que resulte, habida cuenta que, según el numeral 1. del artículo 5 del PIDCP, "ninguna disposición del presente Pacto podrá ser interpretada en el sentido de conceder derecho alguno a un estado, grupo o individuo para emprender actividades o realizar actos encaminados a la destrucción de cualquiera de los derechos y libertades reconocidos en el Pacto o a su limitación en mayor medida que la prevista en él”.

Significa lo anterior que, si el estándar de garantías establecido en un tratado internacional sobre Derechos Humanos no puede ser desconocido o rebajado por el Estado nacional, una interpretación a contrario sensu lleva a entender de manera legítima que resulta del todo viable jurídicamente que los Estados nacionales suban o mejoren dichos estándares de garantías, evento en el cual tendrá que aplicarse el que reconoce mayores niveles de protección y libertad a nivel nacional que el que surge del internacional.

2) Subcláusula explícita:

La consignada en el numeral 2. ${ }^{\circ}$ del artículo 5 del PIDCP, que a la letra dice que "no podrá admitirse restricción o menoscabo de ninguno de los derechos humanos fundamentales reconocidos o vigentes en un Estado parte en virtud de leyes, convenciones, reglamentos o costumbres, so pretexto de que el presente Pacto no los reconoce o los reconoce en menor grado".

Como se puede ver, de manera directa y sin rodeos, se consagra allí el mandato de atender el mejor estándar de garantías que surja de la confrontación de los niveles de protección o libertad ofrecidos a nivel nacional e internacional. 
De manera específica, en cuanto al derecho a la vida y la prohibición de la pena capital, así también lo consagra el numeral $6^{\circ}$ del artículo 6 del PIDCP, según el cual "ninguna disposición de este artículo podrá ser invocada por un Estado Parte en el presente Pacto para demorar o impedir la abolición de la pena capital”.

Las dos subcláusulas mencionadas vienen exigidas también, respectivamente, por los numerales $1 .^{\circ}$ y $2 .^{\circ}$ del artículo 5 del PIDESC.

Particularmente resulta de especial relevancia el artículo 4 del PIDESC, toda vez que, de una manera clara y sin hesitación alguna, excluye, con una interpretación a contrario sensu, la posibilidad de limitar los Derechos Humanos reconocidos en Tratados Internacionales sobre la materia por parte de tratados internacionales diferentes, habida cuenta que especifica que los Estados nacionales podrá limitar los Derechos Humanos exclusivamente mediante ley y "solo en la medida compatible con la naturaleza de esos derechos y con el exclusivo objeto de promover el bienestar general en una sociedad democrática". (Resaltado fuera de texto).

En consecuencia, significa lo anterior que, si las limitaciones a los Derechos Humanos solo son legítimas en tanto tiendan a garantizar racional y razonablemente otros de la misma naturaleza, cualquier limitación por fuera de tal orden básico y esencial resulta total y absolutamente ilegítima.

Por otro lado, en el ámbito americano, el artículo 29 -sobre "Normas de interpretación"- de la CADH señala de manera clara en su literal a), apuntándole a la subcláusula implícita, que ninguna disposición de la Convención puede ser interpretada en el sentido de permitir que un Estado nacional, grupo o persona pueda "suprimir el goce y ejercicio de los derechos y libertades reconocidos en la Convención o limitarlos en mayor medida que la prevista en ella". Por otro lado, el literal b) del mismo artículo consagra también la prohibición de limitar, por parte de la Convención, "el goce y ejercicio de cualquier derecho o libertad que pueda estar reconocido de acuerdo" con las leyes de los Estados nacionales, expresión de la llamada subcláusula explícita.

\subsubsection{La cláusula del respeto mínimo que debe hacerse a nivel nacional de los} estándares de garantías de los derechos y libertades fundamentales vinculadas con las materias punitivas, por supuesto penales y disciplinarias, lo que se conoce como el debido proceso

De manera específica se dice, por el numeral 3. ${ }^{\circ}$ del artículo 14 del PIDCP, que las garantías en él consignadas son "mínimas", lo que nada obsta para su mejora por los estándares nacionales, caso en el cual se preferirá la aplicación de estos.

En cuanto a las "garantías judiciales" también, en el numeral 2. ${ }^{\circ}$ del artículo 8 de la CADH, se establece de manera clara y sin hesitación alguna el carácter de "mínimas" que tienen las allí enunciadas, lo que no obsta para que los estándares nacionales las 
mejoren cuantitativa y cualitativamente, caso en el cual tendrán estas prevalente y preferente aplicación.

\subsubsection{Elementos de control pertenecientes a la esfera del Derecho no escrito}

Para la determinación del mejor estándar de garantías observable en la interpretación y aplicación de la normatividad de los Estados nacionales no solo cuentan las normas positivas contenidas en los Tratados Internacionales sobre Derechos Humanos y otros instrumentos complementarios y de desarrollo no convencionales, sino que también aparecen algunos principios supranormativos vinculados con el Derecho Natural.

Prima facie podría decirse que así viene impuesto desde los considerandos mismos del PIDCP y de la CADH, puesto que su fuente principal, diríase mejor su fundamento y principios más caros, es la idea de dignidad humana y la derivación de allí de todos los demás derechos inalienables que hacen iguales y libres a todos los hombres.

De allí que, con plena coherencia y solidez, se afirme por el literal c) del artículo 29 de la CADH que también son decisivos en la tarea de determinar el mejor estándar de garantías aplicables: i) Otros derechos y garantías que son inherentes al ser humano, debiéndose entender que no se encuentran escritos, y ii) Otros derechos y garantías que se derivan de la forma democrática representativa de gobierno.

Pero además, en una correcta interpretación de contexto, no puede olvidarse que existe igualmente una correlación de derechos y deberes convencionales, como se desprende del artículo 32 de la $\mathrm{CADH}$, lo cual tiene un serio y efectivo impacto en la interpretación y aplicación de los Tratados Internacionales sobre Derechos Humanos.

\subsubsection{Otras consideraciones}

Creemos necesario precisar, además, dos importantes aspectos, pues en ellos aparece la nota destacada en la sentencia T-1319 de 2001:

El artículo 93 de la Constitución contempla dos hipótesis normativas distintas. Cada una de las hipótesis establece mandatos de incorporación al bloque de constitucionalidad, de alcance diferente. El inciso primero incorpora, por vía de prevalencia, los derechos humanos que no pueden limitarse bajo estados de excepción. La norma constitucional no establece relación alguna entre normas constitucionales y las disposiciones que se incorporan al ordenamiento jurídico nacional. De ahí que pueda inferirse que se integran al bloque de constitucionalidad inclusive derechos humanos no previstos en la Constitución, que cumplan con el requisito mencionado. El inciso segundo, por su parte, ordena que los derechos y deberes previstos en la Constitución se interpreten de conformidad con los tratados internacionales sobre derechos humanos ratificados por Colombia. Así, esta vía de incorporación está sujeta a que el derecho humano o 
el deber, tengan su par en la Constitución pero no requiere que el tratado haga referencia a un derecho no suspendible en estados de excepción. La Corte concluye que el artículo 93-2 constitucionaliza todos los tratados de derechos humanos ratificados por Colombia y referidos a derechos que ya aparecen en la Carta y, en virtud de la regla hermenéutica sobre favorabilidad, el intérprete debe escoger y aplicar la regulación que sea más favorable a la vigencia de los derechos humanos. (Resaltado fuera de texto).

De todos modos, es importante señalar cómo, para los efectos de este aparte y del escrito ya referenciado, la Corte Internacional de Justicia en la Opinión Consultiva n. 276 de 1970 precisó que "un instrumento internacional debe ser interpretado y aplicado en el cuadro del conjunto del sistema jurídico en vigor en el momento en que la interpretación tiene lugar"17.

La interpretación de los tratados se configura a partir de reglas lógicas, sistemáticas, teleológicas, axiológicas y sociológicas consignadas en la Convención de Viena sobre el Derecho de los Tratados según las cuales:

1) "Un tratado deberá interpretarse de buena fe conforme al sentido corriente que haya de atribuirse a los términos del tratado en el contex to de estos y teniendo en cuenta su objeto y fin" (numeral 1. de su artículo 31);

2) "Para los efectos de la interpretación de un tratado el contexto comprenderá, además del texto, incluido su preámbulo y anexos", otros elementos de naturaleza sociológica como acuerdos entre las partes referidos al mismo e instrumentos relacionados con lo acordado (numeral 2. ${ }^{\circ}$, literales a y b, de su artículo 31); acuerdos ulteriores sobre su interpretación y aplicación, prácticas referidas a ello y "toda forma pertinente de derecho internacional aplicable en las relaciones entre las partes" (numeral 3. ${ }^{\circ}$, literales a, b y c, de su artículo 31);

3) El sentido especial de ciertas expresiones si consta que ello fue la intención de las partes (numeral $4^{\circ}$ de su artículo 31 );

4) Se tendrán como medios complementarios de interpretación los trabajos preparatorios del tratado y las circunstancias de su celebración bien para confirmar el sentido o desentrañar el mismo ante ambigüedades o posibles interpretaciones que lleven al absurdo o a lo irrazonable, ante la aplicación de las reglas anteriores (artículo 34).

Como se puede ver, allí se encuentran representadas las diferentes visiones de la Dogmática como Ciencia del Derecho, entendida como supramétodo de interpretación

17 Cfr. Romero Pérez, Xiomara Lorena. Vinculación de las resoluciones judiciales de la Corte Interamericana, Bogotá, Universidad Externado de Colombia, 2011, p. 72. 
integral e integrado, en la que se encarna y refleja la jurisprudencia de conceptos, la jurisprudencia teleológica o finalista y la jurisprudencia de valores, donde la siguiente no niega a la anterior, sino que la mejora cuantitativa y cualitativamente en el marco del entendimiento y comprensión de la materia jurídica en los Estados Constitucionales de Derecho ${ }^{18}$.

Finalmente debe quedar claro que, respecto de lo referido al derecho interno de los Estados y la observancia de los tratados, "una parte no podrá invocar las disposiciones de su derecho interno como justificación del incumplimiento de un tratado", según lo establece el artículo 27 de la Convención de Viena sobre el Derecho de los Tratados.

\subsection{El principio de progresividad en materia de estándares de garantía}

El principio de progresividad comporta el entendimiento según el cual, una vez un Estado nacional ha dado un paso adelante en el establecimiento o en el mejoramiento de un estándar de garantía, el mismo se vuelve irreversible.

Pueden identificarse dos formas de aparición de la cláusula de progresividad:

\subsubsection{Genérica}

El principio de progresividad puede ser afirmado a partir del carácter dinámico que tienen las normas internacionales sobre Derechos Humanos, lo cual es evidente ya, desde los considerandos mismos de los PIDCP y PIDESC, puesto que reconocen que su realización en gran medida depende de la creación de "condiciones que permitan a cada persona gozar de sus derechos civiles y políticos, tanto como de sus derechos económicos, sociales y culturales".

Se expresa en dos importantes dimensiones:

1) Progresividad en los estándares y niveles de garantías;

2) Irretractabilidad de las conquistas.

La progresividad viene dada de manera explícita por las normas del Orden Público Internacional de los Derechos Humanos, la irretractabilidad de las conquistas, en el sentido de que cuando son obtenidas se vuelven irreversibles - no en cuanto a su aplicación retroactiva favorable en materias penales-, se determina implícitamente por el concepto de evolución, que en el contexto de los Derechos Humanos implica necesa-

18 Gómez Pavajeau. La Dogmática como Ciencia del Derecho, ob. cit. 
riamente mejora, pues los retrocesos no pueden ser considerados sino como involución o vuelta al pasado.

Ya ello venía sugerido por el espíritu de la declaración Universal de los Derechos Humanos, en cuanto señala que "toda persona tiene derecho a que se establezca un orden social e internacional en el que los derechos y libertades proclamados en esta Declaración se hagan plenamente efectivos" (artículo 28), lo cual involucra conceptualmente la idea de un programa en permanente evolución.

Particularmente ello es propio de la naturaleza de los Derechos Económicos, Sociales y Culturales, tal como se desprende del artículo 2 numerales $1 .^{\circ}$ y $2 .^{\circ}$ de la PIDESC. El primero de ellos es absolutamente claro cuando dispone que su logro debe perseguirse en forma progresiva.

También, de manera clara y evidente, surge de la DADDH, puesto que da cuenta de que los Derechos Humanos en ella consagrados deben entenderse apenas como "un sistema inicial de protección", por lo que necesariamente se entiende como un punto de partida pero no como un punto de llegada, habida cuenta que "deberán fortalecerse cada vez más en el campo internacional” (Considerando n. ${ }^{\circ}$ ). (Resaltado fuera de texto).

Por ello, proclama en su Considerando n. 3 que "la protección internacional de los derechos del hombre debe ser guía principalísima del derecho americano en evolución". (Resaltado fuera de texto).

También esa permanente evolución, que indica que los derechos actualmente reconocidos son necesarios pero no suficientes, tiene expreso reconocimiento:

1) En el Preámbulo de la $\mathrm{CADH}$, cuando señala su "naturaleza convencional coadyuvante o complementaria de la que ofrece el derecho interno de los Estados Americanos"; y

2) En el artículo 31 ibídem, que permite que, a través de procedimientos más ágiles, como los de su artículo 77, se consagren "otros derechos y libertades". Esto es, a través de Protocolos adicionales aprobados por la Asamblea General, se potencian los derechos ya reconocidos "con la finalidad de incluir progresivamente en el régimen de protección de la misma otros derechos y libertades", que se conocen como instrumentos no convencionales pero con valor de fuente jurídica de aplicación a los conflictos que deban ser resueltos ${ }^{19}$.

Creemos que también este sistema de Protocolos, más ágiles que el desarrollo a través de tratados internacionales, mutatis mutandis es aplicable al sistema de Naciones

19 Bovino, Alberto. Instrumentos internacionales de Derechos Humanos no contractuales. Valor jurídico. Disponible en: www.robertexto.com 
Unidas, puesto que el procedimiento ordinario solo es aplicable cuando se trata de enmiendas como lo establecen los artículos 51 del PIDCP y 29 del PIDESC. Cuando se llevan a cabo desarrollos, parece que no existiera la misma formalidad de las enmiendas, pues no se desconoce en ellos ni la letra ni el espíritu siempre y cuando se mejoren los estándares de garantías; los cuales se conocen como reglas de soft law y se expresan en instrumentos que toman el nombre de reglas, principios o directrices ${ }^{20}$, a los que también se ha referido la Corte Constitucional otorgándoles un valor ilustrativo en la interpretación jurídica según sentencia T-077 de 2013.

\subsubsection{Específica}

De manera concreta, en materia del derecho a la vida y la prohibición de la pena de muerte, se encuentra consagrado el principio de progresividad.

En efecto, el numeral 2. ${ }^{\circ}$ del artículo 6 del PIDCP expresa que "en los países que no hayan abolido la pena capital solo podrá imponerse la pena de muerte por los más graves delitos". A su vez, su numeral 6. establece de manera perentoria que "ninguna disposición de este artículo podrá ser invocada por un Estado Parte en el presente Pacto para demorar o impedir la abolición de la pena capital".

También así la CADH a través de dos disposiciones que reafirman mucho más dicho espíritu dinámico, que implica necesariamente progresividad en las mejoras e irretractabilidad de las conquistas (artículo 4 numerales $2 .^{\circ}$ y $3 .^{\circ}$ ):

1) En los países donde exista la pena de muerte la misma solo podrá imponerse "por los delitos más graves";

2) No "se extenderá su aplicación a delitos a los cuales no se la aplique actualmente"; y

3) “No se restablecerá la pena de muerte en los Estados que la han abolido".

\section{INSTITUCIONES PARA HACER EFECTIVO EL DERECHO INTERNACIONAL DE LOS DERECHOS HUMANOS}

\subsection{El principio pro homine o pro libertate}

La doctrina especializada señala que este principio, también conocido como pro personae, se constituye en un criterio hermenéutico "en virtud del cual se debe acudir a la norma más amplia, o a la interpretación más extensiva, cuando se trata de reconocer derechos protegidos, e inversamente, a la norma o a la interpretación más restringida

20 Ibídem. 
cuando se trata de establecer restricciones permanentes al ejercicio de los derechos", lo que implica "estar siempre a favor del hombre" 21 , aclarándose que, "las normas que concurren, pueden ser de carácter internacional y/o nacional, pero en ninguno de estos supuestos se plantea un conflicto de jerarquía, pues el criterio del juez para determinar que norma aplicar, siempre será el mismo: escoger aquella que resulte más favorable para la salvaguarda de los derechos humanos", esto es, "el operador jurídico siempre tendrá que aplicar la norma que reporte más ventajas para la protección de los derechos humanos", afirma ROMERO PÉREZ ${ }^{22}$.

Ello también se extiende a la interpretación de la norma, en tanto debe acudirse a aquella "que sea más extensiva o más benéfica" 23 .

La jurisprudencia constitucional ha señalado que resulta pertinente y es necesario que "en cada caso, la interpretación de las disposiciones jurídicas se lleve a cabo acudiendo a un criterio finalista, que tome en cuenta las metas y objetivos establecidos en la Carta, de acuerdo con los criterios pro-libertatis y pro-homine, derivados de la filosofía humanista que inspira el constitucionalismo colombiano" 24 .

En efecto, es necesario resguardar los derechos fundamentales. La llamada interpretación pro homine cumple un papel vertebral cuando el derecho fundamental al debido proceso pueda verse en oposición a otro valor constitucional, especialmente el referido al interés general, tensión siempre visible cuando a aquel se anteponen justicia como sentimiento de percepción ciudadana y eficacia. No hay duda que allí debe imponerse siempre, y en todo caso, la noción de debido proceso:

Esta Corporación -Corte Constitucional- no duda en señalar que en caso de que no pueda establecerse una armonización concreta de los principios constitucionales en conflicto, debe darse preferencia al derecho fundamental al debido proceso, pues la eficacia de la administración de justicia y la seguridad jurídica no pueden alcanzarse a riesgo de sacrificar los derechos fundamentales de las personas. La justicia está al servicio de esos derechos, por lo cual en estos casos no puede aplicarse mecánicamente el principio constitucional de prevalencia del interés general $\left(\mathrm{CP}\right.$ art. $\left.1^{\circ}\right)$ sobre el particular, pues en tales eventos la norma constitucional relevante es aquella que dispone que el Estado reconoce la primacía de los derechos inalienables de la persona ( $\mathrm{CP}$ art. $\left.5^{\circ}\right)$. Por ello, en caso de

21 PinTo, MónICA. "El principio pro hombre. Criterios de hermenéutica y pautas para la regulación de los derechos humanos", en La aplicación de los tratados de derechos humanos por los tribunales locales, Buenos Aires, Centro de Estudios Legales y Sociales (CELS), Editorial del Puerto, 1977, pp. 163 y ss.

22 Ibídem, pp. 75, 76 y 77.

23 Ibídem, p. 78. Así también la Sala de Casación Penal de la Corte Suprema de Justicia en sentencia de segunda instancia de tutela de julio 31 de 2007, radicación n. ${ }^{\circ} 31.972$, M. P.: SOLARTE PoRTILLA.

24 Corte Constitucional, sentencia C-1026 de 2001. 
conflicto irresoluble entre derechos constitucionales tan fundamentales, como la vida, la libertad o el debido proceso, y la persecución de objetivos estatales de interés general, como los que se logran con una justicia más eficaz, en principio debe el juez constitucional dar prevalencia a los derechos de la persona, pues es la única forma de conferir un efecto interpretativo real a la Carta de derechos. Este criterio hermenéutico es necesario, pues no puede darse preferencia a los intereses de la mayoría y al bienestar colectivo siempre que entran en conflicto con un derecho constitucional de una persona, con el deleznable argumento de que el derecho individual es particular, y el interés general prima siempre sobre el particular. En efecto, conviene recordar que los derechos constitucionales son precisamente limitaciones al principio de mayoría y a las políticas destinadas a satisfacer el bienestar colectivo. Esto significa que, como lo reconoce la doctrina, los derechos fundamentales son verdaderas cartas de triunfo contra el bienestar colectivo pues "condicionar la validez de un derecho constitucional a los criterios de las mayorías es quitarle toda su eficacia específica puesto que, en una gran medida, los derechos constitucionales fundamentales son las promesas que formulan las mayorías a las minorías -y a esas minorías radicales que son las personas- de que su dignidad e igualdad serán siempre respetadas. Por ello debe entenderse que el respeto de esos derechos es un componente integrante del interés general, tal y como esta Corporación lo había señalado”. Sentencia T-669 de $1996^{25}$. (Resaltado fuera de texto).

\subsection{Instrumentos internacionales no convencionales}

Son instrumentos internacionales producidos por los órganos políticos de los sistemas ONU y OEA que se expresan como principios, directrices, reglas, etc., no elevados a la categoría de tratados internacionales pero que llevan la anuencia de los Estados partes, los que en el fondo y en sustancia han manifestado su voluntad en cuanto a la interpretación evolutiva de los Derechos Humanos consignados en aquellos, mostrándose así como sus desarrollos dinámicos.

Sobre ellos ha dicho la doctrina ${ }^{26}$ :

La multiplicidad y el valor de las distintas fuentes han sido reconocidos expresamente. En este sentido, se afirma que el vertiginoso desarrollo del derecho de los derechos humanos "se ha multiplicado en numerosos tratados, principios y otros instrumentos internacionales, que conforman hoy este nuevo corpus normativo" (ABREGÚ, MARTÍN).

25 Ibídem, sentencia T-784 de 2000.

26 Bovino. Ob. cit. 
Debe quedar claro, sin embargo, que más allá del reconocimiento teórico que se les atribuya, estos instrumentos constituyen parte del derecho internacional de los derechos humanos. Respecto a ellos, se manifiesta: "Los órganos políticos de la ONU y de la OEA, si bien carecen de poderes legislativos, constituyen foros que favorecen la formación del Derecho Internacional Consuetudinario, pues facilitan la tarea de comprobar la práctica y la opinio juris de los Estados (O’Donnell). El Juez de la Corte Internacional de Justicia, JimÉnez DE ARÉCHAGA... merece ser citado: 'Por otro lado, la Asamblea General no solo es el órgano principal de las Naciones Unidas, sino también es un órgano formado de representantes de todos los Estados miembros... Esto significa que la Asamblea General es un foro en el que... se reúnen casi todos los Estados, y en el que dichos Estados, después del correspondiente debate, pueden expresar sus opiniones y su voluntad colectiva respecto a los principios y normas jurídicas que han de regir la conducta de los Estados"' (O’DonNELL).

De todos modos, estos instrumentos son fuente de aplicación del Derecho en la medida en que se constituyen en costumbre internacional, en tanto "práctica generalmente aceptada como derecho" (literal b del artículo 38 del Estatuto de la Corte Internacional de Justicia).

Enunciativamente podemos señalar los siguientes a partir de la información suministrada por BoVINO, quedando pendiente como tarea un inventario exhaustivo y completo de dichos instrumentos complementarios, en orden a poner en práctica un litigio que reclame su aplicación en Colombia:

1) Las Reglas Mínimas para el Tratamiento de los Reclusos;

2) Los Principios Básicos para el Tratamiento de los Reclusos;

3) El Conjunto de Principios para la Protección de Todas las Personas Sometidas a Cualquier Forma de Detención o Prisión;

4) Las Reglas de las Naciones Unidas para la Protección de los Menores Privados de Libertad;

5) Reglas Mínimas de las Naciones Unidas para la Administración de la Justicia de Menores (Reglas de Beijing);

6) Las Directrices de las Naciones Unidas para la Prevención de la Delincuencia Juvenil (Directrices de Riad);

7) Las Reglas Mínimas de las Naciones Unidas sobre las Medidas no Privativas de la Libertad (Reglas de Tokio); 
8) Las Directrices sobre la Función de los Fiscales;

9) Los Principios Básicos sobre la Función de los Abogados;

10) Los Principios Básicos relativos a la Independencia de la Judicatura;

11) El Código de Conducta para Funcionarios Encargados de Hacer Cumplir la Ley;

12) Principios de Bangalore sobre la Conducta Judicial.

\subsection{El control de convencionalidad}

Dado el valor jerárquico de los tratados internacionales, por supuesto respetando siempre la interpretación y aplicación de los mismos a partir de la determinación y escogencia vinculante del mejor estándar de garantías que rija una determinada materia, se ha esbozado un concepto jurídico que cada día toma mayor fuerza, según el cual es obligación de toda autoridad de un Estado nacional, pero muy especialmente si la misma tiene la calidad de juez en sentido formal o material, de confrontar y contrastar las normas nacionales e internacionales con la finalidad de ejercer un control de convencionalidad como muestra real, eficaz y eficiente de respeto hacia el valor del Orden Público Internacional de los Derechos Humanos.

En efecto, se ha dicho por la Corte Interamericana de Derechos Humanos que "el poder judicial debe ejercer una especie de control de convencionalidad entre las normas jurídicas internas que aplican en los casos concretos y la Convención Americana sobre Derechos Humanos. En esta tarea el poder judicial debe tener en cuenta no solamente el tratado, sino la interpretación que del mismo ha hecho la Corte Interamericana, intérprete última de la Convención Americana"27.

Recientemente ha señalado 28 :

142. La responsabilidad estatal bajo la Convención solo puede ser exigida a nivel internacional después de que el Estado haya tenido la oportunidad de declarar la violación y reparar el daño ocasionado por sus propios medios. Esto se asienta en el principio de complementariedad (subsidiariedad), que informa transversalmente el Sistema Interamericano de Derechos Humanos, el cual es, tal como lo expresa el Preámbulo de la misma Convención Americana, "coadyu-

27 Corte Interamericana de Derechos Humanos, sentencia de noviembre 24 de 2006, Caso Trabajadores cesados del Congreso vs. Perú, párrafo 128.

28 Corte Interamericana de Derechos Humanos, sentencia de noviembre 30 de 2012, Caso Masacre de Santo Domingo vs. Colombia. 
vante o complementario de la [protección] que ofrece el derecho interno de los Estados americanos". De tal manera, el Estado "es el principal garante de los derechos humanos de la personas, de manera que, si se produce un acto violatorio de dichos derechos, es el propio Estado quien tiene el deber de resolver el asunto a nivel interno y, [en su caso,] reparar, antes de tener que responder ante instancias internacionales como el Sistema Interamericano, lo cual deriva del carácter subsidiario que reviste el proceso internacional frente a los sistemas nacionales de garantías de los derechos humanos" 29 .

Esas ideas también han adquirido forma en la jurisprudencia reciente bajo la concepción de que todas las autoridades y órganos de un Estado Parte en la Convención tienen la obligación de ejercer un "control de convencionalidad" 30 .

143. Lo anterior significa que se ha instaurado un control dinámico y complementario de las obligaciones convencionales de los Estados de respetar y garantizar derechos humanos, conjuntamente entre las autoridades internas (primariamente obligadas) y las instancias internacionales (en forma complementaria), de modo que los criterios de decisión puedan ser conformados y adecuados entre sí.

Se afirma por la doctrina especializada que "el fundamento normativo de este control de convencionalidad estaría en el art. 2. ${ }^{\circ}$ de la Convención Americana, de acuerdo con el cual los Estados partes en ese tratado tienen la obligación de armonizar el derecho interno con las disposiciones de esa convención"31.

29 Caso Acevedo Jaramillo y otros vs. Perú. Interpretación de la Sentencia de excepciones preliminares, fondo, reparaciones y costas. Sentencia de 24 de noviembre de 2006, párr. 66.

30 Cuando un Estado es parte de un tratado internacional como la Convención Americana, todos sus órganos, incluidos sus jueces, están sometidos a aquel, lo cual los obliga a velar por que los efectos de las disposiciones de la Convención no se vean mermados por la aplicación de normas contrarias a su objeto y fin, por lo que los jueces y órganos vinculados a la administración de justicia en todos los niveles están en la obligación de ejercer ex officio un "control de convencionalidad" entre las normas internas y la Convención Americana, evidentemente en el marco de sus respectivas competencias y de las regulaciones procesales correspondientes, y en esta tarea deben tener en cuenta no solamente el tratado, sino también la interpretación que del mismo ha hecho la Corte Interamericana, intérprete última de la Convención Americana. Cfr. Caso Almonacid Arellano y otros vs. Chile. Excepciones preliminares, fondo, reparaciones y costas. Sentencia de 26 de septiembre de 2006. Serie C, n. ${ }^{\circ} 154$, párr. 124; Caso Gomes Lund y otros (Guerrilha do Araguaia) vs. Brasil. Excepciones preliminares, fondo, reparaciones y costas. Sentencia de 24 de noviembre de 2010. Serie C, n. ${ }^{\circ} 219$, párr. 176, y Caso Cabrera García y Montiel Flores vs. México. Excepción preliminar, fondo, reparaciones y costas. Sentencia de 26 de noviembre de 2010. Serie C, ${ }^{\circ}{ }^{\circ} 220$, párr. 225. Véase asimismo Caso Gelman vs. Uruguay. Fondo y reparaciones. Sentencia de 24 de febrero de 2011. Serie C, n. ${ }^{\circ} 221$, párr. 193.

31 Cfr. Romero Pérez, Xiomara Lorena. Vinculación de las resoluciones judiciales de la Corte Interamericana, Bogotá, Universidad Externado de Colombia, 2011, p. 63. 


\subsection{La jurisprudencia y las opiniones consultivas de los tribunales internacionales y su valor jurídico en el orden interno. La doctrina de los órganos cuasi jurisdiccionales}

La Comisión de Derechos Humanos de la ONU es el órgano de supervisión en el Sistema Universal (artículo 28 del PIDCP), cuyos miembros deben desempeñar sus funciones "con toda imparcialidad y conciencia" (artículo 38 ibídem). Es el órgano encargado de conocer y resolver los procesos contenciosos surgidos a raíz de peticiones que le presenten los individuos que se hallen bajo la jurisdicción de los Estados contratantes, relacionadas con la violación de los derechos enunciados en aquel (artículos 1 a 6 del Protocolo Facultativo del Pacto Internacional de Derechos Civiles y Políticos).

Por supuesto, una forma de controlar el cumplimiento por parte de los Estados nacionales de sus compromisos adquiridos en el PIDCP es lo que se decida por los mecanismos de soluciones contenciosas; empero, también cierta supervisión preventiva anima una dinámica progresista, en tanto aquellos tienen la obligación de "presentar informes sobre las disposiciones que hayan adoptado y que den efecto a los derechos reconocidos en el Pacto y sobre el progreso que hayan realizado en cuanto al goce de esos derechos" (artículo 40 numeral $1 .^{\circ}$ ).

La Corte Interamericana de Derechos Humanos tiene funciones jurisdiccionales y con ellas, o a través de las funciones consultivas, conoce de la "interpretación y aplicación" de la CADH (artículos 61 numeral 1. ${ }^{\circ}, 62$ numeral 3. ${ }^{\circ}$ y 63 ).

La Corte a través de sus funciones consultivas da cuenta de "la interpretación de [la CADU] o de otros tratados concernientes a la protección de los derechos humanos en los Estados Americanos", pero resulta de especial relevancia la relacionada con emitir opiniones "acerca de la compatibilidad entre cualquiera de sus leyes internas [de los Estados partes] y los mencionados instrumentos internacionales" (numerales 1. ${ }^{\circ}$ y $2 .^{\circ}$ del artículo 64 de la CADH).

Como se puede ver, sin hesitación alguna, es necesario determinar que toda y absolutamente toda disposición normativa interna de los Estados nacionales resulte compatible con el Orden Público Internacional de los Derechos Humanos, lo que en principio se demanda por el llamado "Control de convencionalidad", del cual nos ocuparemos luego, y, subsidiaria y complementariamente, por lo que disponga la Corte a través de sus decisiones jurisdiccionales.

La doctrina especializada da cuenta de cómo cada día son mayores los reconocimientos que los tribunales constitucionales de los Estados partes hacen del valor vinculante de la jurisprudencia de los tribunales internacionales, lo cual va configurando una costumbre regional e internacional ${ }^{32}$.

32 Cfr. Romero Pérez. Ob. cit., pp. 54 y ss. 
La Corte Constitucional colombiana ha precisado sobre el valor jurídico de la jurisprudencia de los tribunales internacionales sobre Derechos Humanos:

La Constitución dispone que la incorporación se realiza por vía de interpretación: “... se interpretarán de conformidad con los tratados internacionales sobre derechos humanos ratificados por Colombia". Ello obliga a indagar sobre lo que realmente se incorpora por esta vía, pues no puede interpretarse una norma positiva de textura abierta (como las que definen derechos constitucionales) con otra norma que reviste las mismas características. Solo es posible (i) fundir ambas normas (la nacional y la internacional) y (ii) acoger la interpretación que las autoridades competentes hacen de las normas internacionales e integrar dicha interpretación al ejercicio hermenéutico de la Corte. Por ello esta Corte ha señalado, en varias oportunidades, que la jurisprudencia de las instancias internacionales de derechos humanos constituye una pauta relevante para interpretar el alcance de esos tratados y por ende de los propios derechos constitucionales ${ }^{33}$.

En fin, la jurisprudencia de los tribunales es “un criterio relevante para fijar el parámetro de control de normas que hacen parte del ordenamiento interno colombiano", puesto que contiene la interpretación auténtica de los Derechos contenidos en la CADH, para lo cual se cita la sentencia C-370 de 2006, por medio de la cual "se reconoció el carácter vinculante de la jurisprudencia" de dicha corte internacional ${ }^{34}$.

Sobre el valor jurídico de las Opiniones Consultivas de los órganos internacionales, particularmente de la Corte Interamericana de Derechos Humanos, se tiene dicho que

la Corte coincide con el interviniente en que en esta materia es particularmente relevante la doctrina elaborada por la Corte Interamericana de Derechos Humanos, que es el órgano judicial autorizado para interpretar autorizadamente la Convención Interamericana. En efecto, como lo ha señalado en varias oportunidades esta Corte Constitucional, en la medida en que la Carta señala en el artículo 93 que los derechos y deberes constitucionales deben interpretarse "de conformidad con los tratados internacionales sobre derechos humanos ratificados por Colombia”, es indudable que la jurisprudencia de las instancias internacionales, encargadas de interpretar esos tratados, constituye un criterio hermenéutico relevante para establecer el sentido de las normas constitucionales sobre derechos fundamentales ${ }^{35}$.

33 Corte Constitucional, sentencia T-1319 de 2001, M. P.: UPRIMNY YEPES.

34 Corte Constitucional, sentencia C-442 de 2011, M. P.: SIERRA PORTO.

35 Corte Constitucional, sentencia C-010 de 2000, M. P.: MARTínEZ CABALLERo. Reitera la sentencia C-406 de 1996. 
Incluso parecería que el valor de la jurisprudencia se hiciera extensivo también a lo afirmado por órganos cuasijurisdiccionales como es la Comisión Interamericana de Derechos Humanos:

Para efectos del presente caso, el bloque de constitucionalidad relativo a la libertad de expresión ha de estar integrado por las normas internacionales, en particular el Pacto de San José y la Convención Internacional de Derechos Civiles y Políticos, junto con las interpretaciones que de tales textos han presentado la Comisión Interamericana de Derechos Humanos, la Corte Interamericana de Derechos Humanos y Comité de Derechos Humanos de Naciones Unidas. También ha de otorgarse un peso distinto a las opiniones, pues la naturaleza judicial de la Corte Interamericana de Derechos Humanos, y su competencia sobre Colombia, implica que sus opiniones, más que tenidas en cuenta, no pueden ser ignoradas internamente ${ }^{36}$. (Resaltado fuera de texto).

Así tiene que ser, toda vez que la Comisión Interamericana de Derechos Humanos tiene la "función principal de promover la observancia y la defensa de los derechos humanos", estimulando la conciencia sobre los mismos en los pueblos de las Américas, a través de recomendaciones e informes especiales y generales (artículo $41 \mathrm{CADH}$ ). Muy importante, para el cumplimiento de dicha misión y el carácter compulsivo de sus decisiones, resulta el contenido de su artículo 43, según el cual “los Estados Partes se obligan a proporcionar a la Comisión las informaciones que esta les solicite sobre la manera en que su derecho interno asegura la aplicación efectiva de cualesquiera disposiciones de esta Convención”, lo cual pone de presente, a manera de advertencia, la necesidad de llevar a cabo por parte de los Estados nacionales el llamado "Control de convencionalidad".

De no cumplirse con ello, a partir de los principios de subsidiariedad y complementariedad, puede excitarse su competencia y funcionalidad a partir de denuncias o quejas por personas individuales, grupos de personas de entidad no gubernamental reconocida por los Estados (artículos 44 y 46 literal a) de la CADH.

El procedimiento puede concluir con la activación de una solución amistosa o con la presentación de un informe al Estado demandado, en el cual le formulará "las proposiciones y recomendaciones que juzgue adecuadas" (artículos 48 a 50 ibídem).

El carácter compulsivo de lo decidido por la Comisión al emitir el informe implica que la determinación sobre la violación de la CADH u otro instrumento del Sistema Americano no queda librada a la voluntad de los Estados nacionales, pues el órgano cuasi jurisdiccional "hará las recomendaciones pertinentes y fijará un plazo dentro

36 Corte Constitucional, sentencia T-1319 de 2001. 
del cual el estado debe tomar las medidas que le competan para remediar la situación examinada" (artículo 51 ibídem).

De no acatarse lo anterior por los Estados nacionales, la Comisión acudirá ante la Corte, quien decidirá el asunto por medio de un fallo de naturaleza jurisdiccional vinculante y de obligatorio acatamiento (artículos 61 a 69 ibídem).

\title{
3.5 El bloque de constitucionalidad
}

La jurisprudencia constitucional tiene dicho que "las disposiciones que hacen parte del bloque de constitucionalidad ostentan jerarquía constitucional por estar situadas a la altura de las normas del texto de la Carta y forman con él un conjunto normativo de igual rango", por lo que son "verdaderas fuentes del derecho" y "operan como disposiciones básicas que reflejan los valores y principios fundacionales del Estado y también regulan la producción de las demás normas del ordenamiento doméstico. Dado el rango constitucional que les confiere la Carta, las disposiciones que integran el bloque superior cumplen la cuádruple finalidad que les asigna BoBBIO, a saber, servir de 1) regla de interpretación respecto de las dudas que puedan suscitarse al momento de su aplicación; 2) la de integrar la normatividad cuando no exista norma directamente aplicable al caso; 3) la de orientar las funciones del operador jurídico, y 4) la de limitar la validez, de las regulaciones subordinadas" 37 .

En fin, cuando se trata de operar jurídicamente a partir del bloque de constitucionalidad, no se está haciendo otra cosa que aplicar el artículo 4 de la Carta Política bajo el entendido y mandato perentorio y vinculante acerca de que esta es la "norma de normas", esto es, donde la supralegalidad sirve y es la fuente principal de aplicación e interpretación del Derecho.

Por ello se ha retomado en múltiples oportunidades ${ }^{38}$ lo dicho en la sentencia C-225 de 1995 sobre el bloque de constitucionalidad:

\begin{abstract}
Ahora bien, el artículo 93 de la Carta establece la prevalencia en el orden interno de ciertos contenidos de los tratados de derechos humanos ratificados por Colombia. Esta Corte ha precisado que para que opere la prevalencia de tales tratados en el orden interno, es necesario que se den los dos supuestos a la vez, de una parte, el reconocimiento de un derecho humano, y de la otra que sea de aquellos cuya limitación se prohíba durante los estados de excepción.
\end{abstract}

37 Corte Constitucional, sentencia C-067 de 2003, M. P.: MARCo GERARDo MonRoy CABRA. Importantes antecedentes encontramos en las sentencias C-531 de 1993, C-225 de 1995, T-483 y T-568 de 1999 y C-774 de 2001. 
... los convenios de derecho internacional humanitario prevalecen en el orden interno. Sin embargo, ¿cuál es el alcance de esta prevalencia? Algunos doctrinantes y algunos intervinientes en este proceso la han entendido como una verdadera supraconstitucionalidad, por ser estos convenios normas de ius cogens. Esto puede ser válido desde la perspectiva del derecho internacional puesto que, conforme al artículo 27 de la Convención de Viena sobre el derecho de los tratados, una Parte no podrá invocar las disposiciones de su derecho interno como justificación del incumplimiento de un tratado. Con menor razón aún podrán los Estados invocar el derecho interno para incumplir normas de ius cogens como las del derecho internacional humanitario. Pero, desde la perspectiva del derecho constitucional colombiano, esta interpretación debe ser matizada, puesto que la Constitución es norma de normas (CP art. 4. ${ }^{\circ}$ ). ¿Cómo armonizar entonces el mandato del artículo 93, que confiere prevalencia y por ende supremacía en el orden interno a ciertos contenidos de los convenios de derechos humanos, con el artículo $4^{\circ}$ que establece la supremacía no de los tratados sino de la Constitución?

La Corte considera que la noción de "bloque de constitucionalidad", proveniente del derecho francés pero que ha hecho carrera en el derecho constitucional comparado, permite armonizar los principios y mandatos aparentemente en contradicción de los artículos 4. . y 93 de nuestra Carta.

Este concepto tiene su origen en la práctica del Consejo Constitucional Francés, el cual considera que, como el Preámbulo de la Constitución de ese país hace referencia al Preámbulo de la Constitución derogada de 1946 y a la Declaración de Derechos del Hombre y del Ciudadano de 1789, esos textos son también normas y principios de valor constitucional que condicionan la validez de las leyes. Según la doctrina francesa, estos textos forman entonces un bloque con el articulado de la Constitución, de suerte que la infracción por una ley de las normas incluidas en el bloque de constitucionalidad comporta la inexequibilidad de la disposición legal controlada. Con tal criterio, en la decisión del 16 de julio de 1971, el Consejo Constitucional anuló una disposición legislativa por ser contraria a uno de los "principios fundamentales de la República" a que hace referencia el Preámbulo de 1946.

Como vemos, el bloque de constitucionalidad está compuesto por aquellas normas y principios que, sin aparecer formalmente en el articulado del texto constitucional, son utilizados como parámetros del control de constitucionalidad de las leyes, por cuanto han sido normativamente integrados a la Constitución, por diversas vías y por mandato de la propia Constitución. Son pues verdaderos principios y reglas de valor constitucional, esto es, son normas situadas en el nivel constitucional, a pesar de que puedan a veces contener mecanismos de reforma diversos al de las normas del articulado constitucional stricto sensu. 
En tales circunstancias, la Corte Constitucional coincide con la Vista Fiscal en que el único sentido razonable que se puede conferir a la noción de prevalencia de los tratados de derechos humanos y de derecho internacional humanitario (CP arts. 93 y 214 numeral 2. ${ }^{\circ}$ ) es que estos forman con el resto del texto constitucional un "bloque de constitucionalidad", cuyo respeto se impone a la ley. En efecto, de esa manera se armoniza plenamente el principio de supremacía de la Constitución, como norma de normas ( $\mathrm{CP}$ art. $\left.4 .^{\circ}\right)$, con la prevalencia de los tratados ratificados por Colombia, que reconocen los derechos humanos y prohíben su limitación en los estados de excepción (CP art. 93).

Como es obvio, la imperatividad de las normas humanitarias y su integración en el bloque de constitucionalidad implica que el Estado colombiano debe adaptar las normas de inferior jerarquía del orden jurídico interno a los contenidos del derecho internacional humanitario, con el fin de potenciar la realización material de tales valores.

\subsection{La interpretación de las reglas jurídicas positivas a partir de los principios ${ }^{39}$}

La interpretación a partir de principios viene dada por la hermenéutica introducida por el constitucionalismo moderno, expresada hoy muy particularmente, en el tema penal, por los artículos 13 de la Ley 599 de 2000, 24 de la Ley 600 de 2000 y 26 de la Ley 906 de 2004.

Lo decisivo para esta oportunidad es señalar cómo los principios o normas rectoras se constituyen en i) la esencia y orientación del sistema penal en general; ii) prevalecen sobre las demás normas que tienen el carácter de reglas; y iii) sirven como criterios que informan la interpretación de estas.

La Corte Constitucional por sentencia C-775 de 2003 ha avalado la fuerza normativa de las normas o principios rectores de la ley penal y procesal penal colombianas, al señalar que "contienen los postulados básicos, la filosofía y orientación del sistema penal, y están destinadas a regir y guiar la interpretación y aplicación de las normas penales, de tal manera que los diversos desarrollos guarden plena coherencia con estos postulados".

Muy fácilmente puede percibirse, entonces, que este tipo de normas cumple un papel esencial de enlace entre las reglas normativas que definen la materia penal y procesal penal y el bloque de constitucionalidad, a partir de lo cual se cumple con el deber de todo juez de la República de dar aplicación al llamado "control de convencionalidad”.

39 Sobre este tema, por ello allí me remito, he tenido la oportunidad de pronunciarme de manera amplia en mi trabajo Aspectos liberales y sociales del Derecho Penal, Bogotá, Ediciones Nueva Jurídica, 2012. 